\title{
Environmental Sampling FY01 Annual Report - Understanding the Movement of Mercury in the Environment Surrounding the INEEL
}

M. L. Abbott

September 2001

Idaho National Engineering and Environmental Laboratory Bechtel BWXT Idaho, LLC 


\title{
Environmental Sampling FY01 Annual Report Understanding the Movement of Mercury in the Environment Surrounding the INEEL
}

\author{
Michael L. Abbott
}

September 2001

Idaho National Engineering and Environmental Laboratory Idaho Falls, Idaho 83415

Prepared for the

U.S. Department of Energy

Assistant Secretary for Environmental Management

Under DOE Idaho Operations Office

Contract DE-AC07-99ID13727 


\title{
Environmental Sampling FY01 Annual Report
}

\author{
Understanding the Movement of Mercury in the \\ Environment Surrounding the INEEL \\ Michael L. Abbott \\ September 18, 2001
}

\section{INTRODUCTION}

Environmental fate and transport of the toxic air pollutant mercury $(\mathrm{Hg})$ is currently a high-priority regional concern for the INEEL, and national and global concern for the U.S. Environmental Protection Agency (EPA). At the INEEL's Idaho Nuclear Technology and Engineering Center (INTEC), significant quantities (est. $40 \mathrm{~kg} /$ year) of $\mathrm{Hg}$ may have been released over 37 years of Environmental Management's (EM) High-Level Waste (HLW) treatment operations. The EPA is very concerned about the continued global buildup of $\mathrm{Hg}$ in the atmosphere and aquatic ecosystems, and has recently invested heavily in $\mathrm{Hg}$ research to better understand its complex environmental cycling. ${ }^{1,2}$ The Environmental Sampling work began in FY99 as a joint INEEL/U.S. Geological Survey (USGS) field research effort to (a) better understand the fate and potential impacts of $\mathrm{Hg}$ emissions from the INEEL's HLW treatment operations (operational component) and (b) contribute at a national level to the scientific understanding of local, regional, and global $\mathrm{Hg}$ fate and transport (research component). The USGS contributed snow sampling support in the field (Water Resources Division, Salt Lake City) and laboratory analysis of all samples (Wisconsin District Mercury Research Laboratory).

\section{SUMMARY OF FY01 SAMPLING ACTIVITIES}

FY01 sampling activities were done to measure Hg deposition in snow, concentrations in air, reemission flux rates from soil, and to estimate the historical fallout load in lake sediment downwind from the INEEL. A summary of the sampling activities is as follows (Table 1):

- Snow was the primary sampling medium because it is a very efficient scavenger of atmospheric $\mathrm{Hg}$ and because it usually remains on the ground, allowing sampling after the precipitation event. Samples were taken on the INEEL in January $(n=52)$ and February $(n=67)$ and at nine off-site background locations on the Eastern Snake River Plain (ESRP) in December $(n=10)$, January $(n=18)$, February $(\mathrm{n}=16)$, and March $(\mathrm{n}=7)$. Twenty-one additional snow samples were collected on the west slope of the Teton Range in March to assess the cumulative record of $\mathrm{Hg}$ fallout in the preserved winter snowpack there and to investigate the effects of altitude on fallout rates. The snow measurements were done to determine if there was a perceptible increase (above background) in downwind $\mathrm{Hg}$ fallout as a result of emissions from operating INTEC liquid waste treatment operations (primarily the HLLWE) and to build the environmental monitoring data base started in FY00.

- Flux measurements were made to investigate the potential for re-emission losses of historical calciner-deposited $\mathrm{Hg}$ in INEEL soils, which has been postulated as a reason for the low soil concentrations measured near INTEC in $2000^{3,4}$. Soil re-emission losses result from soil reduction of deposited divalent $\mathrm{Hg}(\mathrm{II})$ to non-reactive elemental $\mathrm{Hg}(0)$ which volatilizes to the atmosphere and 
does not locally deposit, thereby reducing the potential risks to human health and the environment. Flux measurements were made using a custom-designed dynamic flux chamber and gold traps at three locations on the INEEL--a high fallout location northeast of INTEC, a low fallout location, and near a known $\mathrm{Hg}$ surface source (CFA-04).

- Lake sediment core layers were sampled to determine if measureable $\mathrm{Hg}$ fallout occurred off the INEEL throughout the history of INEEL calciner operations (1963 to 2000) and to assess the potential for bioaccumulation in the food-chain. Cores were taken at two important wildlife areas immediately downwind from the INEEL - Sandhole Lake at Camas National Wildlife Refuge (NWR) and Mud Lake. Sediment layers (1-cm intervals) were dated using a Cs-137 radiodating technique which will allow estimation of annual $\mathrm{Hg}$ fallout rates since pre-INEEL times. The pending analytical results will then be compared to calciner campaign dates to determine if there is any correlation. In addition to the sediment sampling, limited water sampling $(\mathrm{n}=11)$ was performed to investigate partitioning of $\mathrm{Hg}$ between the water/sediment interface.

Table 1. Summary of the $\mathrm{Hg}$ sampling activities in FY 2001.

\begin{tabular}{|c|c|c|c|c|}
\hline Location & Month/01 \# & \# Samples & Analyzed? & Purpose \\
\hline \multicolumn{5}{|c|}{$\underline{\text { Snow }}$} \\
\hline \multirow{2}{*}{$\begin{array}{l}\text { INTEC 5-km Grid } \\
\text { (Figure 1) }\end{array}$} & Jan $22-24$ & 52 & Yes & \multirow{2}{*}{$\begin{array}{l}\text { Monitoring during HLLWE } \\
\text { operations }\end{array}$} \\
\hline & Feb 27-Mar 1 & 67 & Yes & \\
\hline \multirow{4}{*}{$\begin{array}{l}\text { Background sites (9) } \\
\text { (Figure 2) }\end{array}$} & Dec 18-19 & 10 & Yes & \multirow{4}{*}{$\begin{array}{l}\text { Regional background monitoring } \\
\text { surrounding INEEL }\end{array}$} \\
\hline & Jan $30-31$ & 18 & Yes & \\
\hline & Feb $21-22$ & 16 & Yes & \\
\hline & Mar 28 & 7 & Yes & \\
\hline \multirow[t]{3}{*}{$\begin{array}{l}\text { W. Slope Teton Range }-5 \text { sites } \\
\text { from } 6,000 \mathrm{ft} \text { to } 10,000 \mathrm{ft}\end{array}$} & Mar 2 & 21 & Yes & $\begin{array}{l}\text { 1) Preserved seasonal fallout } \\
\text { record in deep snowpack }\end{array}$ \\
\hline & & & & $\begin{array}{l}\text { 2) Research on altitude effects of } \\
\text { fallout rates }\end{array}$ \\
\hline & & $\underline{\text { Air }}$ & & \\
\hline \multirow[t]{2}{*}{ INTEC Grid - NE1, NE2, NW1 } & & 6 & & 1) Monitoring - HLLWE \\
\hline & & & & $\begin{array}{l}\text { 2) Regional background } \\
\text { monitoring. }\end{array}$ \\
\hline \multicolumn{5}{|c|}{$\underline{\text { Soil-to-Air Flux }}$} \\
\hline $\begin{array}{l}\text { INTEC Grid: 1) 2-km } \\
\text { downwind (NNE) of INTEC } \\
\text { stack ( } 2 \text { samples), 2) 12-km }\end{array}$ & July & $\begin{array}{l}4 \text { samples; } \\
3 \text { chamber } \\
\text { blanks }\end{array}$ & Yes & $\begin{array}{l}\text { 1) Flux chamber testing } \\
\text { 2) Determine fate of past calciner } \\
\text { fallout }\end{array}$ \\
\hline \multicolumn{5}{|c|}{ Lake Sediment/Water } \\
\hline \multirow{2}{*}{$\begin{array}{l}\text { Sandhole Lake, Camas NWR } \\
\text { Mud Lake }\end{array}$} & Jul 25 & $25 / 6$ & No & \multirow{2}{*}{$\begin{array}{l}\text { Historical fallout record from } \\
\text { pre-INEEL times to present, } \\
\text { Potential bioaccumulation in } \\
\text { sensitive downwind areas. }\end{array}$} \\
\hline & Aug 2 & $26 / 6$ & No & \\
\hline
\end{tabular}




\section{METHODS}

\section{Sampling Locations}

Most of the snow sampling on the INEEL was conducted on the INTEC 5-km grid-an array of 64 sampling locations located on 22.5-degree radials at distances of 1, 2, 3, and $5 \mathrm{~km}$ (Figure 1). This grid was designed, based on previous air modeling studies of the INTEC 250 - $\mathrm{ft}$ main stack, ${ }^{5}$ to provide an adequate assessment of the fallout pattern around the facility with a reasonable number of samples. The 10 background sites (Figure 2) were selected based on their location surrounding the INEEL, their likelihood of snowfall accumulation, and winter access. The July flux measurements were made at a high fallout location on the INTEC 5-km (NNE2), at a low fallout location 12-km NW of INTEC, and at a known Hg-contaminated site (CFA-04) (Figure 1). These locations were selected to test the performance of the newly-designed flux chamber system across a wide range of re-emission flux rates. Lake sediment cores were taken at Sandhole Lake, Camas NWR and Mud Lake (Figure 3). These locations were selected based on their downwind location from INTEC (60 km NE) and the INEEL (20 km NE), site research indicating the long-term (pre-INEEL) presence of lake sediment records, and the presence of sensitive aquatic species (fish and aquatic birds) located there.

\section{Snow Sampling and Analytical Methods}

Laboratory analysis of all samples was provided by the U.S. Geological Survey Wisconsin District Mercury Research Laboratory (WDMRL) in Madison, Wisconsin. The WDMRL is one of two fullservice environmental mercury laboratories in the U.S. All sampling is done using laboratory cleaned, Hg-free teflon sampling bottles and shoulder-length gloves.

For snow samples, the snowpack was excavated to the ground and the snow face was cleaned using a clean lexan shovel (Hg sticks to metal). At background sites with significant $(>50 \mathrm{~cm})$ snowpack, a snow pit was dug, and separate composite samples of the old underlying and new top snow were collected. At the INEEL, a composite of the new snow was sampled in December and separate samples of old and new snow were sample d in February. Snow density measurements were made which are later multiplied by the snow depth to determine the snow water equivalent (SWE) at each location (SWE is equivalent to the mass $[\mathrm{kg}]$ or depth of water $[\mathrm{mm}]$ per unit area). After sampling, the bottles were double-bagged, placed into a cooler with dry ice, and shipped frozen to the WDMRL.

In the laboratory, snow samples were melted, acidified (to keep the mercury oxidized and in solution), and analyzed for total mercury ( $\mathrm{THg}) .{ }^{6} \mathrm{THg}$ includes all chemical forms of $\mathrm{Hg}$, including divalent $\mathrm{Hg}(\mathrm{II})$, elemental $\mathrm{Hg}(0)$, and methyl mercury. THg analysis was performed using EPA Method 1631, "Mercury in Water by Oxidation, Purge and Trap, and Cold Vapor Atomic Fluorescence Spectrometry (CVAFS)," with modifications. For some samples, a filtered/unfiltered (FTHg/UTHg) split was analyzed, which can provide information on whether the $\mathrm{Hg}$ was associated with particulate or existed as a gas in the atmosphere (which provides evidence of the fallout source). The WDMRL laboratory uses a rigorous $\mathrm{QA} / \mathrm{QC}$ procedure, which includes duplicate analyses on every sample, spike recovery analyses at least once every 10 samples, quality control check samples, and bubbler blanks to check for background contamination. ${ }^{6}$ 

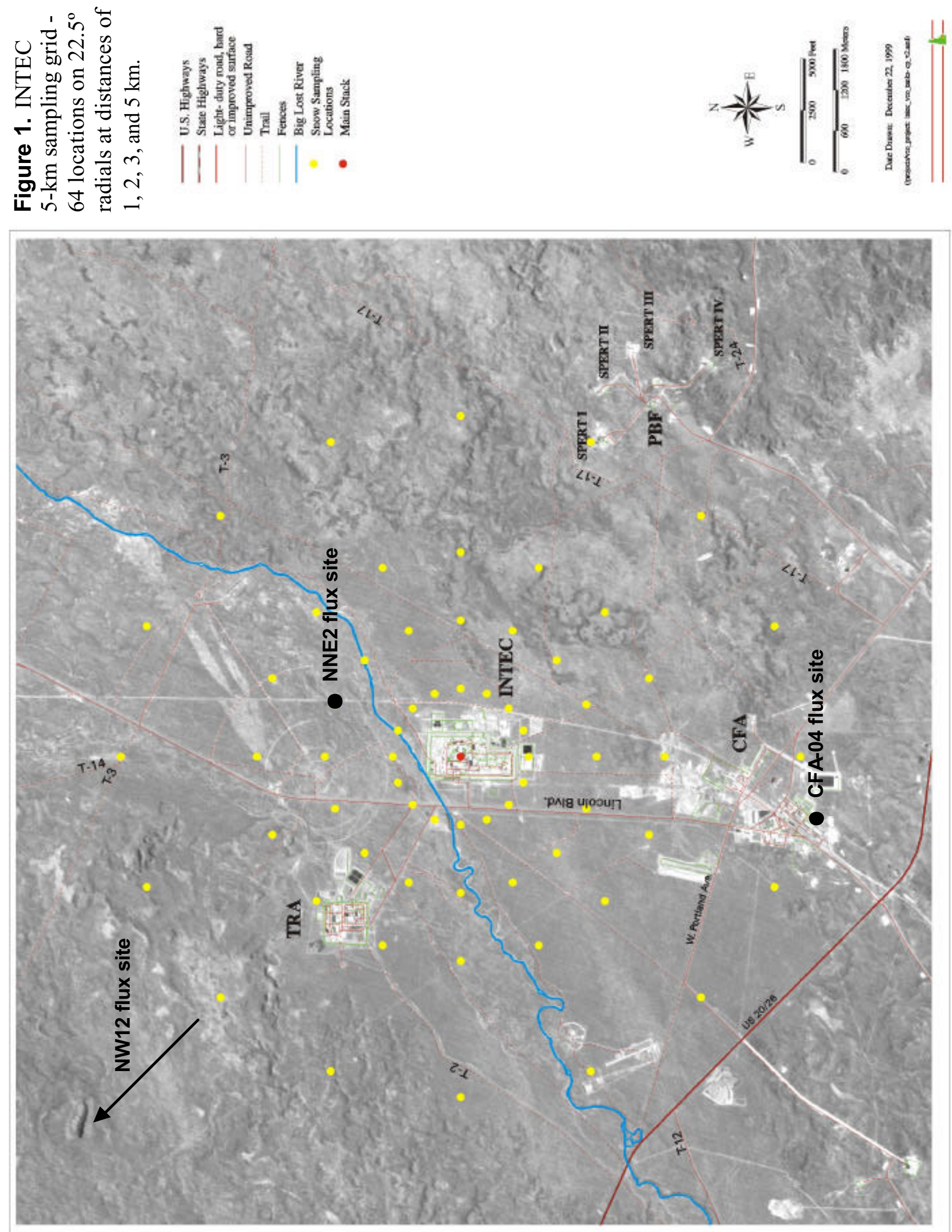


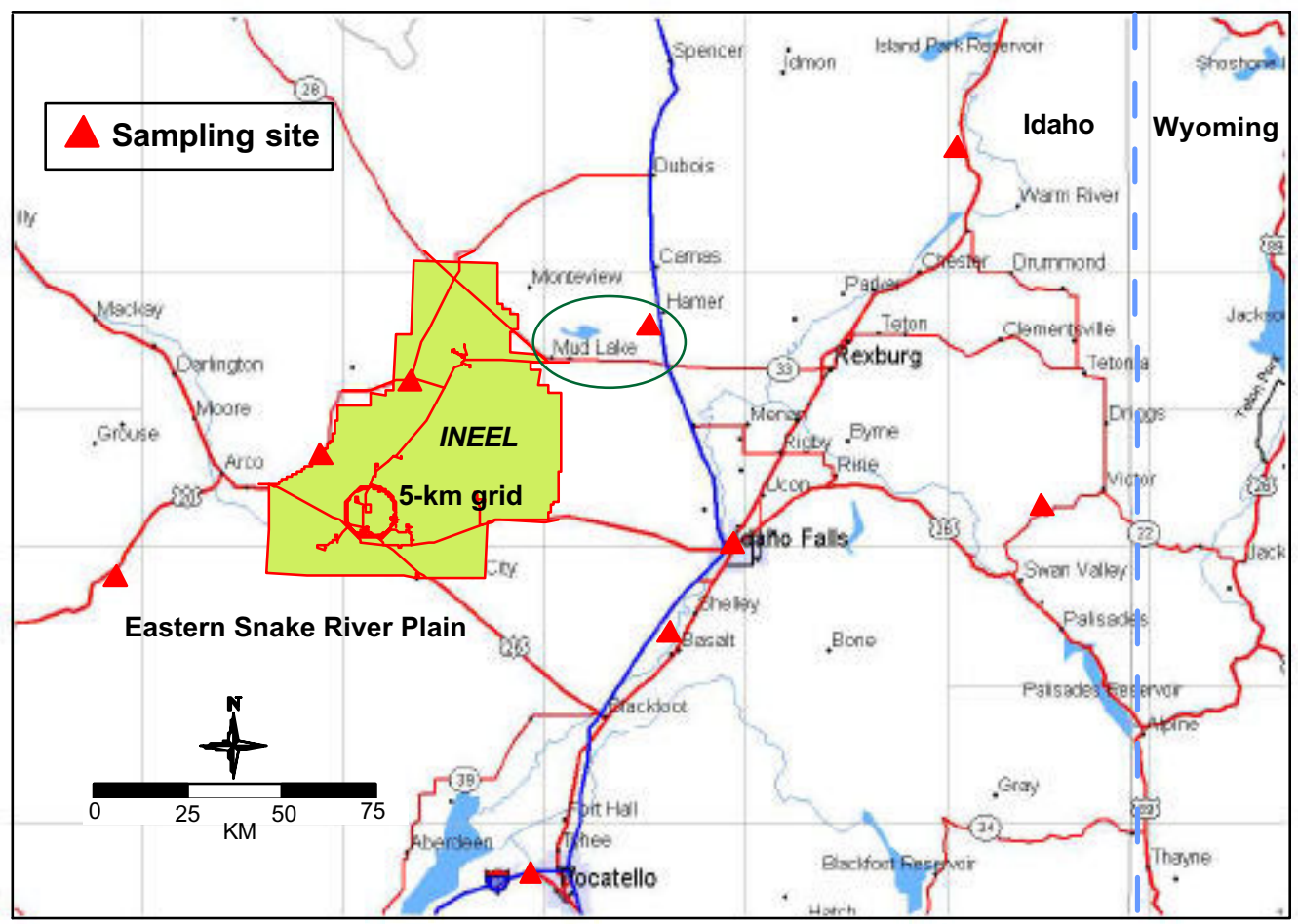

Figure 2. ESRP background sampling sites and Mud Lake/Camas sediment sampling area (circled).

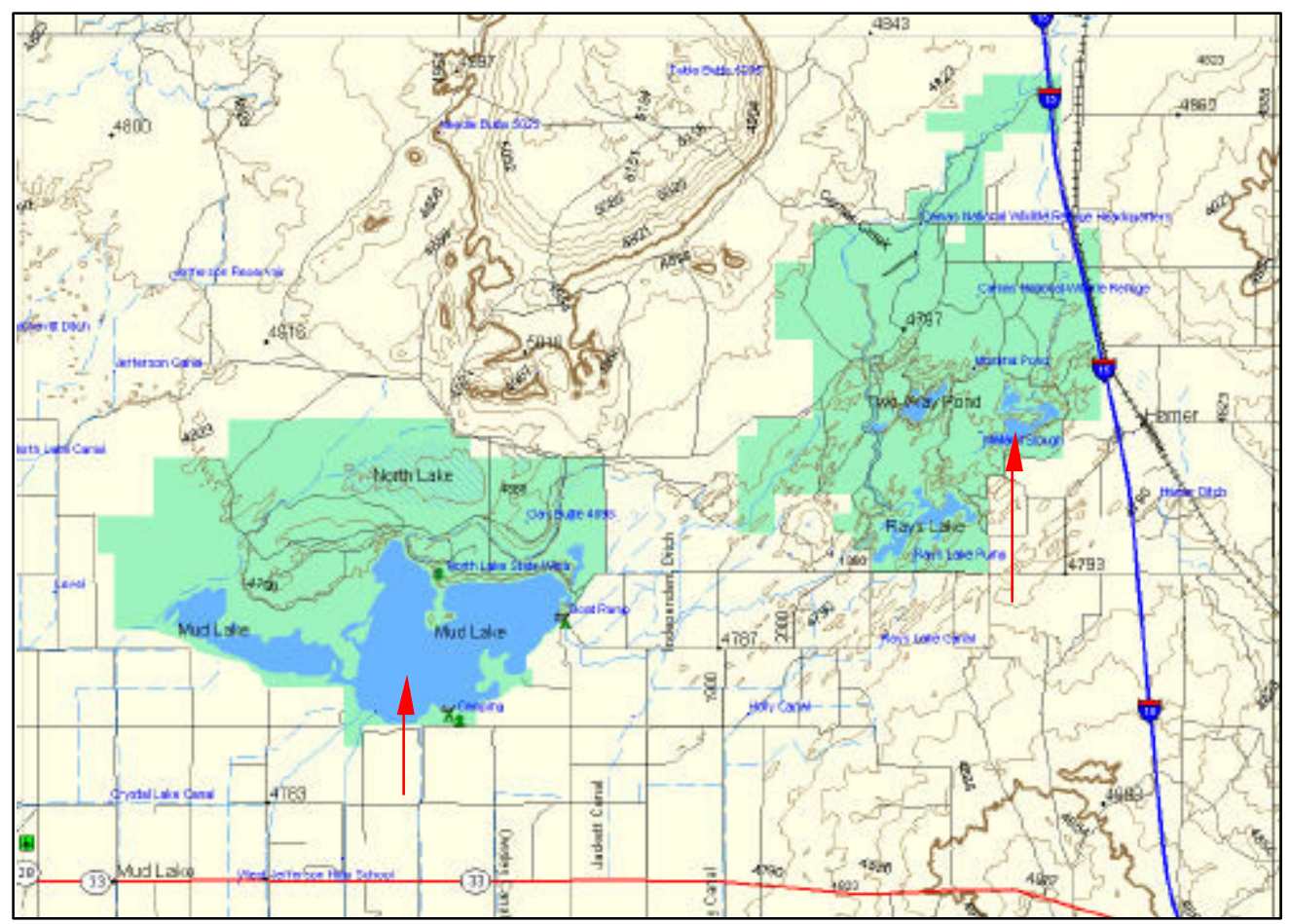

Figure 3. Location of sediment sampling at Mud Lake (left arrow) and Camas NWR (right arrow). 


\section{Soil Re-emission Flux Measurements}

An experimental dynamic flux chamber system (Figure 4) was designed and tested to measure reemission flux rates of previously deposited $\mathrm{Hg}$ from soil to the atmosphere. Re-emission of deposited $\mathrm{Hg}$ has been previously postulated as a reason for the low $\mathrm{Hg}$ soil concentrations measured in FY00 near INTEC. It is important to better understand this process because $\mathrm{Hg}$ is re-emitted to the air as $\mathrm{Hg}(0)$ which does not locally deposit and therefore does not contribute to local risk, either to humans or the environment.

The flux chamber theory and design is based on numerous published studies, including the work of Carpi and Lindberg $(1998)^{7}$ and Gustin et al. $(1999)^{8}$. The chamber itself is a simple polycarbonate pastry cover with four inlet holes (open to air) and four outlet holes on the opposite side through which air is drawn $(20 \mathrm{~L} / \mathrm{min}$ ) by a high capacity vacuum pump (Figure 4$)$. Two portable air samplers with mass flow controllers (Bios ${ }^{\circledR}$ AirPro) are used to pull air $(1 \mathrm{~L} / \mathrm{min})$ through two replicate gold traps, one pair of traps being used to sample near the chamber inlet and one pair used to sample a side stream from the chamber outlet line. Teflon tubing is used throughout, to reduce $\mathrm{Hg}$ adsorption, and the air is pre-filtered ( $0.45 \mathrm{um}$ teflon) prior to the goldtraps to eliminate $\mathrm{Hg}$ in entrained dust. A 1-hour sampling time (0.06 $\mathrm{m}^{3}$ of air) is used which provides ample $\mathrm{Hg}(100 \mathrm{pg})$ for laboratory detection/quantification at normal $\mathrm{Hg}$ background levels $\left(1-2 \mathrm{ng} / \mathrm{m}^{3}\right)$. After sampling, the gold traps are removed using ultra-clean handling techniques (shoulder-length gloves/double bagged), placed in a cooler, and mailed to the WDMRL.

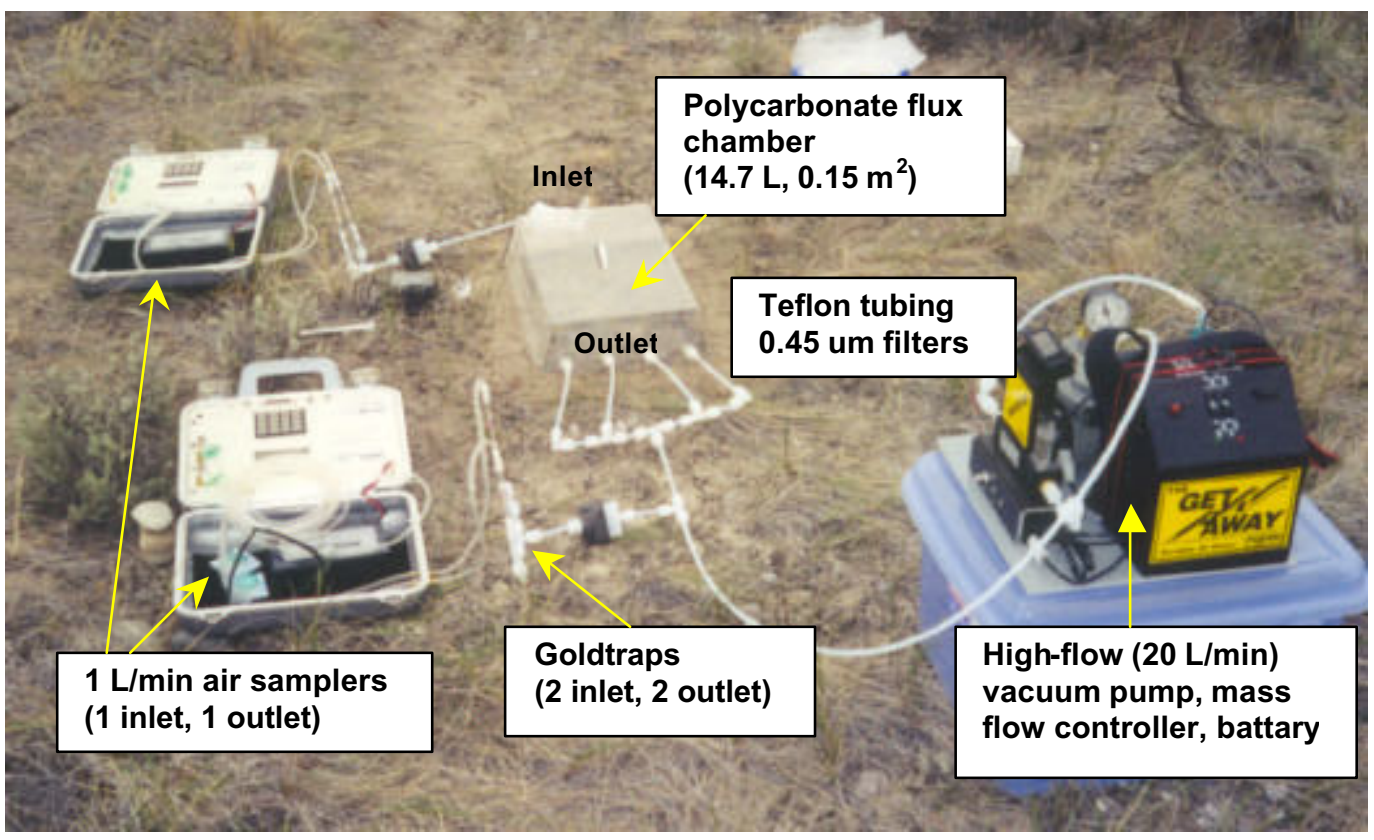

Figure 4. Dynamic flux chamber system used to measure re-emission of $\mathrm{Hg}$ on the INEEL.

One-hour samples were taken at three locations on the INEEL (Figure 1): at a high fallout location 2-km north-northeast of INTEC (NNE2, [2 measurements]), a background location 12-km northwest of INTEC, and adjacent to a known Hg contaminated area (CFA-04). "Chamber blank" runs-1-hour samples with a teflon sheet between the soil surface and flux chamber--were made at each location to test 
the performance of the system. Good system performance is demonstrated by no significant difference between the inlet and outlet $\mathrm{Hg}$ concentrations during the chamber blank runs. A difference in these two concentrations might be caused by air flow measurement errors, leaks in the system, or absorption of the $\mathrm{Hg}$ onto surfaces of the sampling system. Re-emission flux rate from the soil ( $\mathrm{F}$, in $\mathrm{ng} / \mathrm{m}^{2} / \mathrm{hr}$ ) is calculated as:

$F=\frac{\left(C_{0}-C_{i}\right)}{A} \times Q$

where

$\mathrm{C}_{\mathrm{o}}=$ average of outlet gold trap concentrations $\left(\mathrm{ng} / \mathrm{m}^{3}\right)$

$\mathrm{C}_{\mathrm{i}}=$ average of inlet gold trap concentrations $\left(\mathrm{ng} / \mathrm{m}^{3}\right)$

$\mathrm{Q}=$ total flow rate through flux chamber (chamber pump + outlet $\operatorname{Bios}{ }^{\circledR} \operatorname{pump}\left[\mathrm{m}^{3} / \mathrm{hr}\right]$ )

$A=$ bottom surface area of flux chamber $\left(0.15 \mathrm{~m}^{2}\right)$

\section{Lake Sediment Sampling}

Lake sediment cores (approx. 30-cm long) were obtained using two methods. At Sandhole Lake Camas NWR, where maximum lake depths were about $3 \mathrm{ft}$., an individual waded out from shore, pushed a 8-cm diameter (3-in) by 40-cm long butyrate plastic tube into the sediment bed, capped the tube underwater, and extracted the core (Figure 5). During extraction, no sediment was lost because of the partial vacuum created by the top cap. At Mud Lake, where samples were taken from a boat in 8-ft. of water, a Wildco ${ }^{\circledR}$ hand coring device with 5-cm (2-in) diameter plastic liner was used with a 10-ft. extension handle. After obtaining a core, a plunger assembly was used to vertically extrude 1-cm sections of the core into a retaining ring, where the sections were sliced-off and placed into sample bottles.

A total of 9 cores (5-cm and 8-cm dia) were taken at Sandhole Lake on 7/5,7/10,7/16, and 7/25, and 6 cores were taken at Mud Lake on 7/24 and 8/2. The initial cores were taken to develop the sampling procedure, determine the variation in porosity at the site, and to perform a $\mathrm{Cs}^{137}$ radiodating screen (see Core Dating, below) at 5-cm depth intervals. Based on the results of the $\mathrm{Cs}^{137}$ screening and analytical cost considerations, it was decided that 30-long cores would be taken, and samples would be collected in 1-cm intervals from the sediment-water interface to a depth of $25 \mathrm{~cm}$. Final core sampling at Sandhole (7/25) was done by combining 1-cm depth intervals from 2 replicate 8 -cm diameter cores to obtain enough sample for the $\mathrm{Cs}^{137}$ analyses $\left(60 \mathrm{~cm}^{3}\right)$ and $\mathrm{Hg}$ analyses $\left(20 \mathrm{~cm}^{3}\right)$. At Mud Lake, composite samples from five replicate 5 -cm diameter cores were required to do the porosity ( 1 core), $\mathrm{Cs}^{137}$ ( 3 cores), and $\mathrm{Hg}$ analyses ( 1 core). Ultraclean sampling techniques were used when performing the $\mathrm{Hg}$ sampling, and the samples were double-bagged and placed into a cooler with dry ice. Porosity measurement were made at the Idaho Research Center (IRC) by dividing the water mass (= water volume at $1 \mathrm{~g} / \mathrm{cm}^{3}$ ) in a sample by its volume. The $\mathrm{Cs}^{137}$ analyses were done by high resolution GeLi gamma spectroscopy at the Radiological Measurements Laboratory (RML), Test Reactor Area (TRA). The Hg samples were place into a cooler with dry ice and sent frozen to the WDMRL for analysis. Sediment samples were analyzed similar to the snow samples except that a subsample was first taken and then digested in a mixture of nitric and sulfuric acid. 

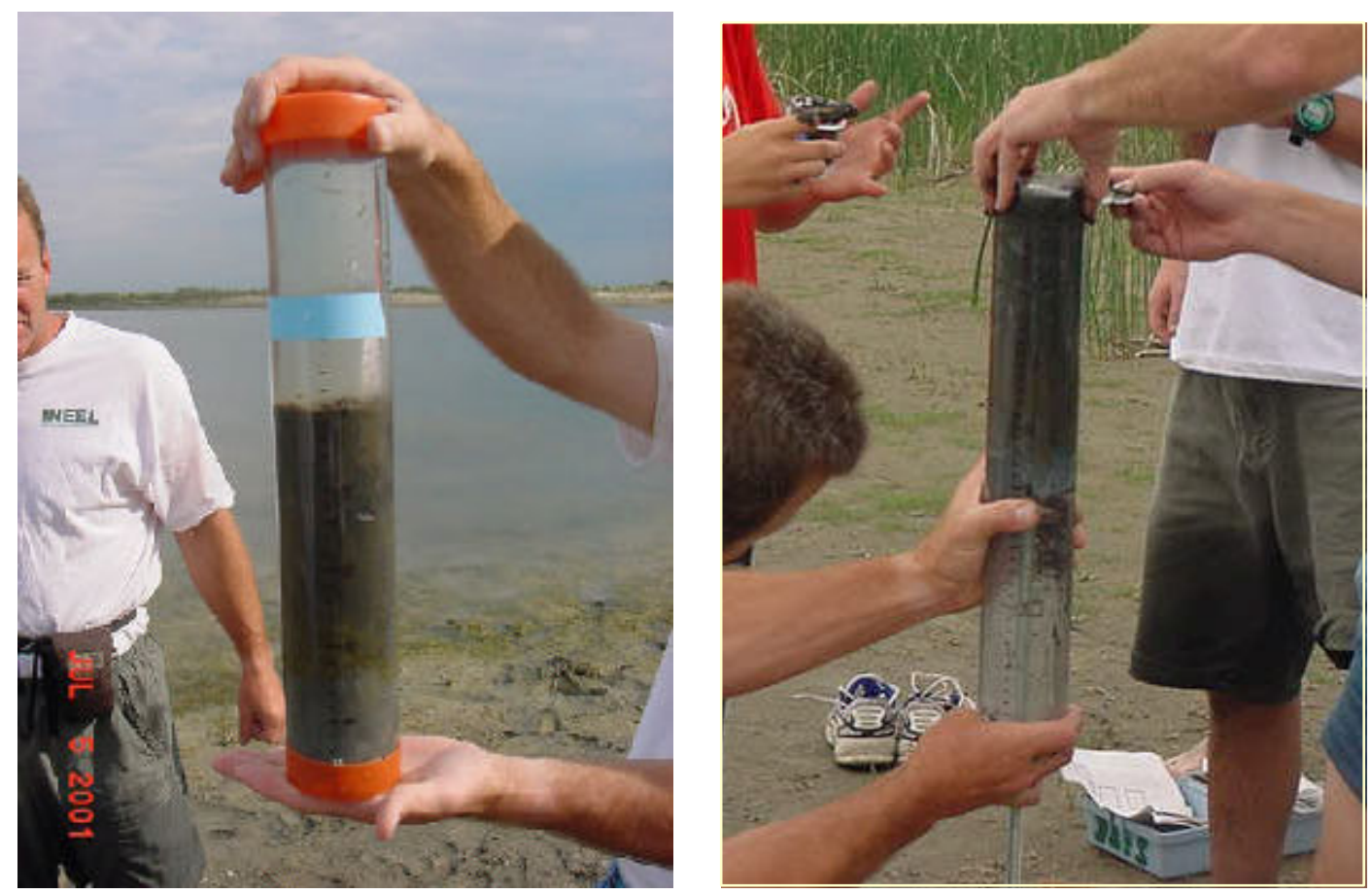

Figure 5. Lake sediment core (3-in dia) taken at Sandhole Lake, Camas National Wildlife Refuge (left); extrusion and sectioning of the core into 1-cm intervals for samples (right).

Core Dating: Cesium-137 analyses and porosity measurements were made to radiodate (assign the year of fallout to) the 1-cm depth intervals of the core. Assuming no fluvial input or post-depositional mixing (minor at both sampling sites), lake sediment layers are formed by an annual accumluation of atmospheric dust and other airborne fallout. Based on previous studies ${ }^{9}$, the first occurrence of global weapons test fallout of $\mathrm{Cs}^{137}$ is known to have occurred in 1951/1952, and the peak fallout period has generally been found to be 1963/1964 (assumed to be 1964.0). By identifying the 1964 peak in the sediment profile and knowing the date of the surface layer (sampling date), a fallout date can be estimated for other sediment depths based on dry mass accumulation using the following procedure:

1. Using porosity (P) and assumed particle mass density of $2.5 \mathrm{~g} / \mathrm{cm}^{3}$, calculate the dry mass of sediment in each 1-cm sediment interval (DM in $\left.\mathrm{g} / \mathrm{cm}^{2}\right)$ :

$$
D M=(1-P)\left(2.5 \mathrm{~g} / \mathrm{cm}^{3}\right)(1 \mathrm{~cm})
$$

2. Calculate the total cumulative dry mass $\left(\mathrm{TCDM}\right.$ in $\left.\mathrm{g} / \mathrm{cm}^{2}\right)$ from the 1964 peak layer to the surface (2001.5 sampling date) layer:

$$
\mathrm{TCDM}=\sum_{1964.0}^{2001.5} \mathrm{DM}
$$

3. Calculate the annual dry mass accumulation rate across the sediment core (MAR, in $\mathrm{g} / \mathrm{cm}^{2} / \mathrm{yr}$ ):

$$
\text { MAR } \left.=\frac{\text { TCDM }}{(2001.5-1964.0)} \quad \text { (assumed to be constant over time }\right)
$$


4. Calculate the cumulative dry mass (CDM) from the surface to each sediment layer.

5. Calculate the fallout date for each sedment layer:

Date $=2001.5-\frac{\text { CDM }}{\text { MAR }}$

\section{RESULTS AND DISCUSSION}

\section{Snow Sampling}

A summary of the $\mathrm{Hg}$ snow sampling results (ng/L in new snow layers only) for the INEEL and background sites is provided in Table 2. In January, $\mathrm{Hg}$ concentrations $1 \mathrm{~km}$ from INTEC $(4.7 \mathrm{ng} / \mathrm{L})$ were higher than those at 2-km to 5-km radii (2.5-2.9 ng/L), suggesting a slight INTEC source contribution. However, $\mathrm{Hg}$ concentrations at all INTEC grid sites $(3.2 \mathrm{ng} / \mathrm{L}$ average) were not significantly different than those across the ESRP background sites (3.8 $\mathrm{ng} / \mathrm{L}$ average). During February, the concentrations at all INTEC grid sampling locations were very low $(0.63 \mathrm{ng} / \mathrm{L}$ average $)$ compared to the background sites $(3.46 \mathrm{n} / \mathrm{L})$. The low grid concentrations during this time period may have been due to one or more of the following Hg loss processes in the INEEL snowpack: 1) photo-reduction of the $\mathrm{Hg}(\mathrm{II})$ to volatile $\mathrm{Hg}(0)$, 2) leaching of the $\mathrm{Hg}(\mathrm{II})$ during thaw periods, or 3$) \mathrm{Hg}$ evasion associated with snow sublimation. The relatively high concentrations observed at Ashton Hill ( $7.7 \mathrm{ng} / \mathrm{L})$ are thought to be due to the natural Hg-enriched Yellowstone Rhyolite deposits in that area.

These snow sampling results demonstrate that, from mid-December 2000 through February 2001, INTEC liquid waste treatment operations did not cause any significant increases in environmental $\mathrm{Hg}$ concentrations, either on-site or off-site. All of the measured concentrations are well below the EPA Maximum Contaminant Limit (MCL) for $\mathrm{Hg}$ in drinking water $(2,000 \mathrm{ng} / \mathrm{L})$, although this criterion is not appropriate for judging the indirect impacts from long-term buildup of $\mathrm{Hg}$ in the environment (both to biota and humans). It is well known that direct human intakes from environmental $\mathrm{Hg}$ concentrations in air and water across the U.S. are of little concern, but that some environmental systems can still accumulate these low levels of $\mathrm{Hg}$ to environmentally harmful levels. 
Table 2. Summary of THg concentrations in new (upper) layers of snowpack in FY01.

\begin{tabular}{|c|c|c|c|c|}
\hline \multirow{2}{*}{$\begin{array}{l}\text { Sampling } \\
\text { Location }\end{array}$} & \multirow{2}{*}{$\begin{array}{c}\text { No. } \\
\text { samples }\end{array}$} & \multicolumn{3}{|c|}{ THg Concentration in Snow (ng/L) } \\
\hline & & High & Low & Avg. \\
\hline \multicolumn{5}{|c|}{ INTEC Grid-Jan: } \\
\hline $1 \mathrm{~km}$ radius & 15 & 8.04 & 1.68 & 4.69 \\
\hline $2 \mathrm{~km}$ radius & 16 & 5.12 & 2.04 & 2.88 \\
\hline $3 \mathrm{~km}$ radius & 15 & 3.48 & 1.32 & 2.45 \\
\hline \multirow[t]{2}{*}{$5 \mathrm{~km}$ radius } & 6 & 3.98 & 2.22 & 2.85 \\
\hline & & & Average $=$ & 3.22 \\
\hline \multicolumn{5}{|c|}{ Background Sites - Dec/Jan: } \\
\hline Hell's Half Acre & 2 & 2.16 & 1.31 & 1.74 \\
\hline Idaho Falls (IRC) $^{1}$ & 1 & 1.81 & 1.81 & 1.81 \\
\hline Pine Creek Pass & 2 & 7.01 & 1.61 & 4.31 \\
\hline Ashton Hill & 2 & 8.41 & 7.03 & 7.72 \\
\hline Camas NWR & 2 & 7.85 & 0.90 & 4.37 \\
\hline Lemhi & 2 & 4.88 & 2.10 & 3.49 \\
\hline Lost River & 2 & 4.75 & 1.47 & 3.11 \\
\hline Craters of the Moon & 2 & 3.60 & 1.30 & 2.45 \\
\hline \multirow[t]{2}{*}{ Pocatello STP ${ }^{2}$} & 3 & 5.88 & 4.74 & 5.17 \\
\hline & & & Average $=$ & 3.80 \\
\hline \multicolumn{5}{|c|}{ INTEC Grid - Feb: } \\
\hline $1 \mathrm{~km}$ radius & 15 & 1.52 & 0.47 & 0.82 \\
\hline $2 \mathrm{~km}$ radius & 16 & 1.11 & 0.33 & 0.56 \\
\hline $3 \mathrm{~km}$ radius & 15 & 0.87 & 0.31 & 0.53 \\
\hline \multirow[t]{2}{*}{$5 \mathrm{~km}$ radius } & 6 & 0.74 & 0.49 & 0.61 \\
\hline & & & Average $=$ & 0.63 \\
\hline \multicolumn{5}{|c|}{ Background Sites - Feb/Mar: } \\
\hline Hell's Half Acre & 1 & -- & -- & 4.11 \\
\hline Idaho Falls (IRC) $^{1}$ & 3 & 4.58 & 2.55 & 2.55 \\
\hline Pine Creek Pass & 3 & 6.79 & 2.31 & 5.23 \\
\hline Ashton Hill & 3 & 7.12 & 4.28 & 5.39 \\
\hline Camas NWR & 1 & -- & -- & 3.76 \\
\hline Lemhi & 1 & -- & -- & 1.69 \\
\hline Lost River & 1 & -- & -- & 4.45 \\
\hline Craters of the Moon & 1 & -- & -- & 1.02 \\
\hline \multirow[t]{2}{*}{ Tetons - West side } & 5 & 5.25 & 1.32 & 2.96 \\
\hline & & & Average $=$ & 3.46 \\
\hline
\end{tabular}




\section{Soil Re-emission Flux Measurements}

The results from the flux measurements are shown in Table 3. The following observations are made on these data:

- The NNE2 high fallout location 2-km north-northeast of INTEC showed positive (soil-to-air) net reemission fluxes of 49 to $99 \mathrm{ng} / \mathrm{m}^{2} / \mathrm{hr}$. Net flux is the difference between the soil-to-air re-emission and the air-to-soil fallout of $\mathrm{Hg}$ (from background + local sources). These results suggest that this location is losing $\mathrm{Hg}$ from the soil faster than it is being deposited. For comparison, Carpi and Lindberg ${ }^{7}$ measured positive net fluxes of 20 to $55 \mathrm{ng} / \mathrm{m}^{2} / \mathrm{hr}$ in open fields with direct sunlight near Oak Ridge National Laboratory.

- The low fallout location 12-km northwest of INTEC showed a negative flux of $-16 \mathrm{ng} / \mathrm{m}^{2} / \mathrm{hr}$. These results suggest that fallout (likely from background sources) is slightly exceeding any soil re-emission of $\mathrm{Hg}$.

- The CFA-04 Hg-contaminated site showed an expected very high flux of $1244 \mathrm{ng} / \mathrm{m}^{2} / \mathrm{hr}$, even though the measurements were taken outside the fenced area of this site. For comparison, Gustin et al. ${ }^{8}$ reports measured fluxes of up to $600 \mathrm{ng} / \mathrm{m}^{2} / \mathrm{hr}$ at a naturally $\mathrm{Hg}$-enriched area in Nevada.

The chamber blank runs showed negative fluxes at each of the measurement sites, indicating a potential problem with the system. Subsequent investigation revealed a leaky inlet port on the chamber vacuum pump which resulted in a lower than metered (and unknown) flow rate through the chamber (the Bios ${ }^{\circledR}$ flow rates through the gold traps were not affected). To correct for this, the chamber blank run fluxes were subtracted from the measured fluxes at each site (the measurements were increased by the amount of negative flux measured in the chamber blanks). In spite of this correction, the fluxes shown in Table 3 are suspect because low chamber flushing rates have been shown to depress $\mathrm{Hg}$ flux ${ }^{8}$. Therefore, no certain conclusions are made from these results at this time. Additional flux measurements are planned in FY02 using the Tekran analyzer, which will allow numerous rapid flux measurements to be made in-house across a wide variety of sites and climatic conditions. 
Table 3. Results from re-emission flux measurements.

\begin{tabular}{|c|c|c|c|c|c|c|c|c|c|}
\hline \multirow{2}{*}{ Site } & \multirow[b]{2}{*}{ Trap ID } & \multirow{2}{*}{$\begin{array}{l}\text { Date/ } \\
\text { Time }\end{array}$} & & \multicolumn{2}{|c|}{ Bios volume (m3) } & \multirow{2}{*}{$\begin{array}{c}\text { Mass } \\
(\mathrm{ng})\end{array}$} & \multirow{2}{*}{$\begin{array}{c}\text { Conc. } \\
\text { (ng/m3) }\end{array}$} & \multicolumn{2}{|c|}{ Bios flow rate (L/min) } \\
\hline & & & & meter & corrected & & & meter & corrected \\
\hline \multirow{12}{*}{$\begin{array}{c}\text { NNE2 } \\
\text { run } 1 \\
\text { High Fallout }\end{array}$} & 253 & $06 / 05 / 01$ & Ch 1 In & 0.029 & 0.038 & 0.097 & 2.55 & 0.82 & 1.074 \\
\hline & 260 & 11:20 AM & $\mathrm{Ch} 2 \mathrm{In}$ & 0.030 & 0.034 & 0.072 & 2.10 & 0.86 & 0.978 \\
\hline & & & Avg & & & & 2.33 & & \\
\hline & & & StDev & & & & 0.32 & & \\
\hline & 112 & & Ch 1 Out & 0.037 & 0.041 & 0.139 & 3.41 & 1.00 & 1.104 \\
\hline & 92 & & Ch 2 Out & 0.037 & 0.040 & 0.306 & 7.74 & 1.00 & 1.074 \\
\hline & & & Avg & & & & 5.58 & & \\
\hline & & & StDev & & & & 3.06 & & \\
\hline & & & Main line & & & & & 18.45 & \\
\hline & & & Total flow & & & & & 20.63 & \\
\hline & & & & & & & 99 & \multicolumn{2}{|c|}{$=$ Flux (ng/m2/hr) } \\
\hline & 129 & & trip blank 1 & & & 0.007 & & & \\
\hline \multirow{12}{*}{$\begin{array}{c}\text { NNE2 } \\
\text { run } 2 \\
\text { High Fallout }\end{array}$} & 276 & $06 / 05 / 01$ & Ch 1 In & 0.050 & 0.066 & 0.353 & 5.39 & 0.84 & 1.102 \\
\hline & 261 & $2: 50 \mathrm{PM}$ & Ch $2 \ln$ & 0.051 & 0.058 & 0.319 & 5.49 & 0.87 & 0.987 \\
\hline & & & Avg & & & & 5.44 & & \\
\hline & & & StDev & & & & 0.07 & & \\
\hline & 103 & & Ch 1 Out & 0.060 & 0.066 & 0.967 & 14.66 & 1.01 & 1.107 \\
\hline & 124 & & Ch 2 Out & 0.060 & 0.064 & 0.257 & 4.01 & 1.01 & 1.075 \\
\hline & & & Avg & & & & 9.33 & & \\
\hline & & & StDev & & & & 7.53 & & \\
\hline & & & Main line & & & & & 19.00 & \\
\hline & & & Total flow & & & & & 21.18 & \\
\hline & & & & & & & 49 & \multicolumn{2}{|c|}{$=$ Flux $(\mathrm{ng} / \mathrm{m} 2 / \mathrm{hr})$} \\
\hline & 243 & & \begin{tabular}{|l|} 
trip blank 3 \\
\end{tabular} & & & 0.009 & & & \\
\hline \multirow{12}{*}{$\begin{array}{c}\text { NW12 } \\
\text { Low Fallout }\end{array}$} & 133 & $06 / 06 / 01$ & Ch 1 In & 0.050 & 0.066 & 0.562 & 8.59 & 0.84 & 1.106 \\
\hline & 74 & 11:30 AM & Ch 2 In & 0.051 & 0.058 & 0.358 & 6.15 & 0.86 & 0.979 \\
\hline & & & Avg & & & & 7.37 & & \\
\hline & & & StDev & & & & 1.72 & & \\
\hline & 282 & & Ch 1 Out & 0.059 & 0.065 & 0.331 & 5.10 & 1.00 & 1.098 \\
\hline & 254 & & Ch 2 Out & 0.060 & 0.064 & 0.345 & 5.37 & 1.00 & 1.071 \\
\hline & & & Avg & & & & 5.24 & & \\
\hline & & & StDev & & & & 0.19 & & \\
\hline & & & Main line & & & & & 18.60 & \\
\hline & & & Total flow & & & & & 20.77 & \\
\hline & & & & & & & -16 & \multicolumn{2}{|c|}{$=$ Flux $(\mathrm{ng} / \mathrm{m} 2 / \mathrm{hr})$} \\
\hline & 258 & & \begin{tabular}{|l|} 
trip blank 5 \\
\end{tabular} & & & 0.007 & & & \\
\hline \multirow{12}{*}{$\begin{array}{l}\text { CFA-04 } \\
\text { Hg Site }\end{array}$} & 266 & $06 / 06 / 01$ & Ch 1 In & 0.038 & 0.050 & 0.806 & 16.20 & 0.85 & 1.110 \\
\hline & 256 & $3: 12 \mathrm{PM}$ & $\mathrm{Ch} 2 \ln$ & 0.038 & 0.043 & 0.729 & 16.83 & 0.86 & 0.978 \\
\hline & & & Avg & & & & 16.52 & & \\
\hline & & & StDev & & & & 0.45 & & \\
\hline & 265 & & Ch 1 Out & 0.045 & 0.050 & 7.737 & 156.29 & 1.00 & 1.101 \\
\hline & 275 & & Ch 2 Out & 0.045 & 0.048 & 7.605 & 157.94 & 1.00 & 1.073 \\
\hline & & & Avg & & & & 157.12 & & \\
\hline & & & StDev & & & & 1.16 & & \\
\hline & & & Main line & & & & & 18.50 & \\
\hline & & & Total flow & & & & & 20.67 & \\
\hline & & & & & & & 1244 & \multirow{2}{*}{\multicolumn{2}{|c|}{$=$ Flux (ng/m2/hr) }} \\
\hline & 267 & & trip blank 7 & & & 0.007 & & & \\
\hline
\end{tabular}




\section{Lake Sediment Sampling}

The results from the $\mathrm{Cs}^{137}$ core screening done at Sandhole on July 10, 2001 (Figure 6) show a well-defined peak at a depth of $17.5 \mathrm{~cm}$ and a curve that is similar to those found for lakes across the U.S. in other published studies. ${ }^{9,10}$ The laboratory results for the final $\mathrm{Cs}^{137}$ and $\mathrm{Hg}$ core interval samples from both Sandhole and Mud Lake have not yet been received and will be reported in a revision to this report when received (expected October 2001).
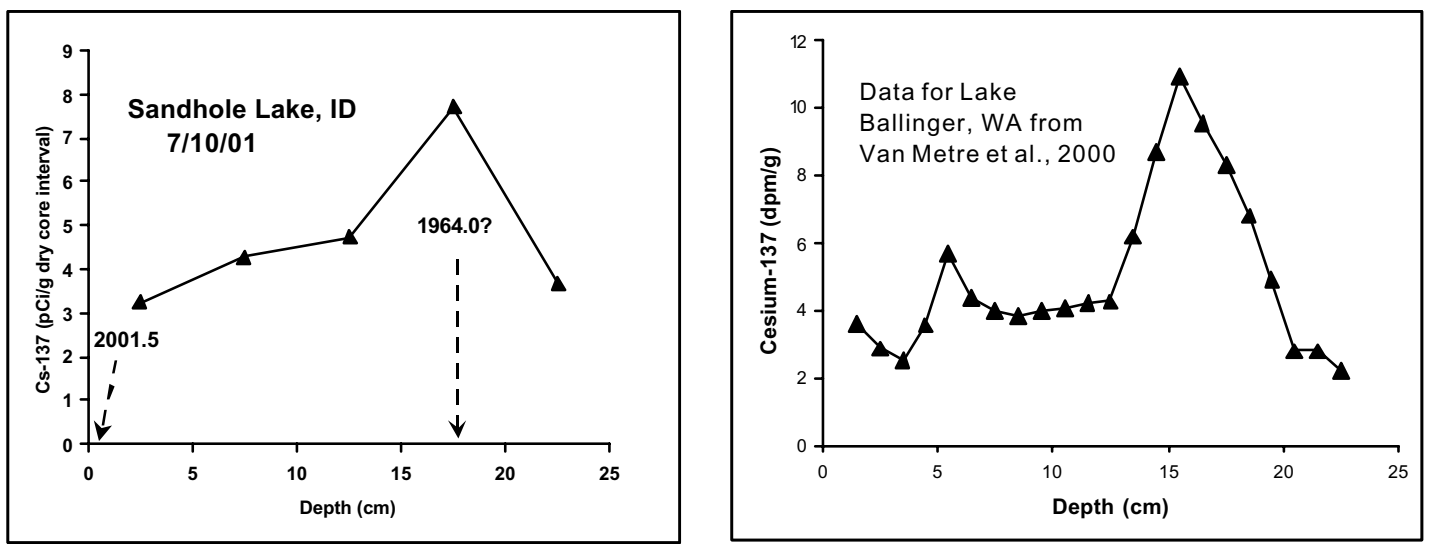

Figure 6. $\mathrm{Cs}^{137}$ concentrations in lake sediment observed in this study (left) and those from another published study ${ }^{10}$ for a lake in Washington.

\section{OTHER ACCOMPLISHMENTS}

A Science Action Team (SAT - INEEL pre-College Education Program) consisting of 1 teacher and 4 students was sponsored and mentored over the summer. The team assisted in the development of procedures and the performance of the lake sediment sampling, and was recognized by the Pre-College Education Program as one of the more successful SAT projects this summer. A presentation was made to interested INEEL staff scientists and DOE-ID, and the team has developed a poster presentation for display at the Idaho Science Teachers Association (ISTA)/INEEL Science Odyssey and Expo on October 4, 2001.

A Tekran 2537A Hg analyzer was purchased which is a state-of-the-science cold vapor atomic fluorescence spectrometer being used by leading U.S. Hg research scientist and various agency research branches (e.g., EPA Office of Research and Development). This instrument provides ultra-low (sub-ppt) near real-time measurements of $\mathrm{Hg}$ in air and will advance the technical research capabilities of the INEEL at a national level. Other Tekran support systems purchased include a primary calibration system, 2-port sampling controller (for performing flux chamber measurements), and an instrument trailer (customized 7-ft.x 14-ft. Hallmark ${ }^{\circledR}$ cargo trailer) for stand-alone deployment of the system in the field (planned for FY02).

The following publications and presentations on the INEEL Hg research were accomplished in FY01:

1. Abbott, M.L., D.D. Susong, D.P. Krabbenhoft, "Mercury Deposition in Snow near an Industrial Emission Source in Southeastern Idaho and Comparison to ISC3 Model Predicitons," accepted by Water, Air, and Soil Pollution, 24 July 2001. 
2. Abbott, M.L., D.D. Susong, D.P. Krabbenhoft, M.L. Olson, "Mercury Distribution in Soil Near a Major Atmospheric Emission Source at the Idaho National Engineering and Environmental Laboratory in Southeastern Idaho," presentation to the Geological Society of America (Summit 2000) Annual Meeting, November 9-18, 2000, Reno, NV. http://www.geosociety.org/pubs/abstracts/2000/50248

3. Abbott, M.L., D.D. Susong, D.P. Olson, M.L., Krabbenhoft, "Mercury in Soil Near a Longterm Emission Source in Southeastern Idaho," invited paper submitted for a special edition of Environmental Geology, May 2001.

Based on the results of this $\mathrm{Hg}$ research, the INEEL has been included as a collaborator with the University of Wisconsin-Madison in a 3-year (6/02-5/05) U.S. EPA-sponsored (\$900K) Science to Achieve Results (STAR) Program Proposal entitled: "Speciated Atmospheric Mercury: Gas/Paricle Partitioning, Transformations, and Source Characterization."

\section{CONCLUSIONS AND RECOMMENDATIONS}

The snow sampling results indicate that during January and February 2001, High Level Waste treatment operations did not result in any significant increase in downwind $\mathrm{Hg}$ fallout, either on- or offsite. A small increase in the snow $\mathrm{Hg}$ concentrations close to $(1-\mathrm{km})$ the INTEC main stack observed in January suggest a possible INTEC source contribution, but the concentrations are still within the range of ESRP background concentrations observed during the same period. Periodic monitoring of precipitation (rain or snow) around INTEC is recommended during future HLW waste treatment operations to confirm that these operations are not increasing background $\mathrm{Hg}$ concentrations at other time periods. Additional measurements will also contribute to building a reliable baseline database that will be valuable for judging the relative impacts from future INEEL waste treatment operations and will continue to build the INEEL's research capabilities at a national level in this area.

The relatively high $\mathrm{Hg}$ re-emission flux measured in soils near INTEC compared to that measured at a distant background site (12 km northwest) continue to reinforce the theory that INEEL surface soil chemistry and/or climatic conditions cause most of the atmospherically-deposited $\mathrm{Hg}$ to be re-emitted (as elemental $\mathrm{Hg}$ ). However, because of the sampling error (flux chamber pump leakage) incurred in this year's measurements, additional measurements are recommended in FY02. Both soil and snow flux measurements are needed under different climatic conditions to fully understand $\mathrm{Hg}$ cycling at the INEEL.

The Mud Lake/Camas sediment core $\mathrm{Hg}$ and $\mathrm{Cs}^{137}$ lab analyses need to be completed and analyzed in FY02 to determine the chronological record of historical annual $\mathrm{Hg}$ fallout from pre-INEEL time to the present. This annual fallout record can then be compared to the historical calciner operating campaigns that began in $1963^{11}$ to determine if any correlation exists. The initial core dating done this year and the locations of these sites immediately downwind from the INEEL suggests that these measurements will provide excellent undisturbed records of historical INEEL atmospheric fallout. Because lake sediments are known to trap and retain $\mathrm{Hg}$, these analyses should provide strong evidence on whether HLW Operations have caused any perceptible increase in regional $\mathrm{Hg}$ levels. Understanding the full impact of past operations will provide an important gauge to assess the relative impacts from future waste treatment operations (e.g., if no impact from historical calciner operations can be detected, then planned treatment processes with the same or smaller $\mathrm{Hg}$ emissions should not be of concern). In addition to investigating the historical record, the potential $\mathrm{Hg}$ bioaccumulation in sensitive aquatic 
species will be predicted using the measured sediment concentrations and published sediment-to-biota bioaccumulation factors.

Field installation, testing, and operation of the newly purchased Tekran ${ }^{\circledR} 2537 \mathrm{~A} \mathrm{Hg}$ vapor analyzer is planned for FY02. This instrument will provide the INEEL with an in-house capability to provide near realtime ultra-low monitoring of total $\mathrm{Hg}$ in the atmosphere at any field location around INTEC or other INEEL facilities. The system will be deployed in a self-contained mobile instrument trailer (purchased this year) with an accompanying portable meteorological (met) station. The met station will provide wind direction data that, when coupled with the Tekran measurements, will provide important source location information during monitoring. Current plans are to do initial set-up/testing of the instrument at the Idaho Research Center (IRC) followed by initial deployment in the winter FY02 at the Experimental Field Station (EFS), about $5 \mathrm{~km}$ north-northeast (downwind) of the INTEC main stack. Operating procedures, QA/QC procedures, and a sampling plan will be developed. When used with the 2-port sampling unit, the Tekran will provide the INEEL with an in-house capability to rapidly perform surface flux chamber measurements at numerous locations and under a wide range of seasonal climatic conditions.

\section{REFERENCES}

1. Environmental Protection Agency, Mercury Study Report to Congress (Vols. I-VIII), http://www.epa.gov/oar/mercury.html, EPA-452/R-003 through 010, December 1997,.

2. Environmental Protection Agency, "Mercury Research Strategy," NCEA-I-0710 Workshop Review Draft, November 1999.

3. Environmental Systems Research Candidates Program FY2000 Annual Report, INEEL/EXT-0001351, January 2001.

4. Abbott, M.L., D.D. Susong, D.P. Olson, M.L., Krabbenhoft, "Mercury in Soil Near a Long-term Emission Source in Southeastern Idaho," invited paper submitted for a special edition of Environmental Geology, May 2001.

5. M. L. Abbott, K. N. Keck, R. E. Schindler, R. L. VanHorn, N. L. Hampton, and M. B. Heiser, Screening Level Risk Assessment for the New Waste Calcining Facility, INEEL/EXT-97-00686 Rev. 5a, May 1999.

6. M. L. Olson and J. F. DeWild, "Techniques for the Collection and Species Specific Analysis of Low Levels of Mercury in Water, Sediment and Biota," D. W. Morganwalp and H. T. Buxton (eds.), U.S. Geological Survey Toxic Substances Hydrology Program--Proceedings of the Technical Meeting, Charleston, SC, USA, March 8-12, 1999, Volume 2 of 3-Contamination of Hydrologic Systems and Related Ecosystems: U.S. Geological Survey Water-Resources Investigations Report, 99-4018A, 1999, pp. 191-201.

7. A. Carpi, S.E. Lindberg, "Application of a Teflon Dynamic Flux Chamber for Quantifying Soil Mercury Flux: Tests and Results over Background Soil," Atmospheric Environment, Vol. 32, No. 5, 1998, pp. 873-882. 
8. M. S. Gustin et al., "Nevada STORMS Project: Measurement of Mercury Emissions from Naturally Enriched Surfaces," Journal of Geophysical Research, Vol. 104, No. D17, September 20, 1999, pp. 21,831-21,844.

9. P.C. Van Metre, E. Callender, C.C. Fuller, "Historical Trends in Organochlorine Compounds in River Basins Identified Using Sediment Cores from Reservoirs," Environmental Science and Technology, 31, 1997, 2399-2344.

10. P.C. Van Metre, B. J. Mahler, E.T. Furlong, "Urban Sprawl Leaves Its PAH Signature," Environmental Science and Technology, 34, 4064-4070.

11. M.D. Staiger, "Calciner Waste Storage at the Idaho Nuclear Technology and Engineering Center," INEEL/EXT-98-00455, June 1999. 